\title{
SUBJECTIVE WELL-BEING (SWB): PNS DAN NON PNS YANG BERSUKU KUTAI ( STUDY INDIGENOUS)
}

\author{
SUBJECTIVE WELL-BEING (SWB): PNS AND NON PNS WHO ARE KENDAI \\ (INDIGENOUS STUDY)
}

Emilda Rifi Yusnita

Fakultas Psikologi, Universitas 17 Agustus 1945 Samarinda

Email : emildarifi9021@gmail.com

\begin{abstract}
Abstrak: Subjective Well-Being merupakan suatu hal yang penting dalam hidup, karena dengan bahagia setiap orang pasti merasakan kenyamanan. Nilai-nilai budaya yang berbeda mempunyai pengaruh terhadap kognitif, emosi, motivasi dan sistem perilaku individu (Markus dan Kitayama,1991 dalam Boyun Woo, 2009). Penelitian bertujuan agar peneliti serta pembaca mengetahui Bagaimana perspektif PNS dan Non PNS bersuku Kutai mengenai subjective well- being dan Faktor - Faktor yang mempengaruhi SWB. Penelitian ini menggunakan pendekatan kualitatif (study indigenous). Partisipan dalam penelitian ini berjumlah 200 orang, yaitu PNS dan Non PNS bersuku Kutai. Model sampling dalam penelitian ini menggunakan teknik snow ball sampling, dengan alat pengumpul data berupa open-ended questionnaire. Hasilnya diketahui bahwa SWB menurut Suku kutai adalah jika mereka memiliki Rasa Puas (34.00\%), Nilai Spiritual (33.50\%), Kebersaman Keluarga (12.50\%), Kesuksesan Pekerjaan (38.00\%), Kecukupan Materi (11.00\%), Pencapaian/Keinginan (29.50\%), Hubungan Sosial (10.00\%). Faktor-faktor yang memengaruhi SWB Suku Kutai adalah Faktor Hubungan Sosial, Faktor Kecukupan Materi / Permasalahan Keuangan, Faktor Kesuksesan pekerjaan.
\end{abstract}

Kata Kunci: Suku Kutai, PNS dan Non PNS, Subjective Well-Being.

Abstract: Subjective Well-Being is an important thing in life, because happily everyone must feel comfortable. Different cultural values have an influence on the cognitive, emotional, motivational and behavioral systems of individuals (Markus and Kitayama, 1991 in Boyun Woo, 2009). The research aims to allow researchers and readers to know how the perspective of PNS and Non PNS with Kutai tribe on subjective well-being and factors influencing SWB. This study used a qualitative approach (study indigenous). Participants in this study amounted to 200 people, namely PNS and Non Civil Solder Kutai. Sampling model in this research using snow ball sampling technique, with data collection tool in the form of open-ended questionnaire. The result is known that SWB according to Kutai Tribe is if they have Sense of Satisfaction (34.00\%), Spiritual Value (33.50\%), Family Taste (12.50\%), Job Success (38.00\%), Material Sufficiency (11.00\%), Achievement / 29.50\%), Social Relations (10.00\%). Factors influencing SWB of Kutai Tribe are Social Relation Factor, Material Adequacy Factor / Financial Problem, Job Success Factor.

Keywords: Kutai Tribe, PNS and Non PNS, Subjective Well-Being. 


\section{PENDAHULUAN}

Masyarakat Indonesia merupakan suatu masyarakat majemuk yang memiliki keanekaragaman di dalam berbagai aspek kehidupan. Bukti nyata adanya kemajemukan di dalam masyarakat kita terlihat dalam beragamnya kebudayaan di Indonesia. Tiap suku bangsa inilah yang kemudian mempunyai ciri kahas kebudayaan yang berbeda-beda terkait dengan komunitas dan identitas sosial.

Suku Kutai adalah suku asli Kalimantan Timur, tepatnya berada di kabupaten Kutai Kartanegara. Suku kutai tersebar di dalam 18 wilayah kecamatan dan 238 desa/kelurahan (kutaikartanegar.com). Kutai kaya akan sumber daya alam yang dapat dihasilkan dari berbagai macam sektor perekonomian, pertanian, perkebunan dan pertambangan (Batubara,Minyak dan Gas Bumi). Kabupaten Kutai Kartanegara yang merupakan kabupaten yang menerima dana bagi hasil sumberdaya alam terbesar di Indonesia sebesar Rp. 2.556,55 Milyar (Kementerian Keuangan, 2009). Namun apakah saat ini kebahagian dan kesejahteraan masih dapat dirasakan bagi masyarakat kalimantan Timur? Banyak Kasus-kasus PHK (Pemutusan Hubungan Kerja) yang menimpa karyawan yang bekerja di sektor pertambangan.

Dari permasalahan yang terjadi saat ini dampak terbesar sangat dirasakan oleh karyawan-karyawan lokal yang sudah tidak lagi mendapatkan kesejahteraan dari pekerjaannya sekarang. Survey awal yamg dilakukan oleh peneliti pada masyarakat Tenggarong diketahui lebih banyak mencoba pekerjaan lainnya untuk memenuhi kebutuhan sehari-hari dan tidak banyak juga masyarakat Non PNS yang mulai mencari-cari peluang untuk menjadi tenaga honorer, Hasil wawancara yang dilakukan oleh peneliti ke berberapa orang masyarakat kutai yang berprofesi sebagai PNS dan Non PNS disimpulkan bahwa masyarakat Kutai lebih cenderung memilih pekerjaan yang dapat menjamin kehidupan hingga akhir masa tua yaitu sebagai PNS dan begitu pun dengan Masyarakat yang Non PNS mereka mengatakan jika ada peluang yang dapat membantu mereka mereka kearah pekerjaan yang lebih terjamin mereka akan berusaha untuk mencoba, seperti dengan menjadi tenaga honorer dapat membantu jalan mereka untuk menjadi seorang PNS.

Dibuktikan dengan adanya berita didapat oleh peneliti, dikutip dari surat kabar kaltim-tibunnews, selasa 21 Februari 2012 yang menyebutkan hingga tahun 2010, jumlah pegawai Negeri Sipil (PNS) di kabupaten Kutai kartanegara mencapai 25.078 orang. Jumlah tersebut terbanyak di Kaltim dan mungkin terbanyak di Indonesia. Bahkan jumlah PNS Kukar mengalahkan jumlah PNS kota Samarinda yang hanya 10.283 Orang.

Dari hasil survey wawancara awal yang dilakukan,peneliti menyimpulkan bahwa kondisi masyarakat yang bersuku Kutai untuk mencapai kesejahteraan, kebahagian dan kenyaman hidup dapat diperoleh dengan menjadi PNS. Hal ini dipilih dengan alasan yang menurut mereka akan masa depan lebih terjamin. Hal ini dibuktikan dengan gaji/upah yang sesuai dan permanen, memperoleh dana kesehatan, jaminan hari tua dan lain-lain. Menurut mereka menjadi seorang PNS lebih gampang dari pada harus berdagang maupun bertani. Hal ini terkait dengan sistem kekeluargaan khas kutai yang disebut "bubuhan" yang sangat erat sehingga dapat saling membantu dalam memberikan informasi.

Penelitian yang akan dilakukan oleh peneliti tidak jauh dari permasalahan yang telah diungkap oleh berberapa peneliti terdahulu, yang melakukan penelitian serupa mengenai subjective well-being, kebahagian dan kekuatan karakter pada suku-suku di Indonesia.

Pada penelitian kali ini penulis ingin melakukan peneltian yang serupa tentang masyarakat Kutai yang bekerja sebagai PNS dan Non PNS. Hal ini dilatarbelakangi penelitian terdahulu bahwa setiap suku mempunyai persepsi yang berbeda-beda dalam memaknai arti kebahagian dan kesejahteraan,dalam kesempatan kali ini peneliti ingin melakukan penelitian mengunakan Pendekatan Studi Indigenous, dapat menekankan tentang perilaku dan cara berpikir seseorang dalam konteks budayanya (Mujamiasih,2013). Setiap suku memiliki kebudayaan yang berbeda. 


\section{METODE PENELITIAN}

\section{Pendekatan Penelitian}

Indigenous Psychology, yaitu pendekatan yang dilihat dari sudut pandang budaya lokal, agar data yang diperoleh asli dalam realitas Indonesia sendiri, sehingga setiap fenomena dipandang menurut konteks, dipapar, serta ditafsirkan secara relatif berdasarkan situasi budaya dan ekologi tempat fenomena berlangsung. Kim dan Berry (1993) mendefinisikan indigenous psychology sebagai kajian ilmiah mengenai perilaku dan mental manusia yang bersifat pribumi,tidak dibawa dari daerah lain, dan didesain untuk masyarakatnya sendiri. Tujuan indigenous psychology adalah untuk menciptakan pendekatan terstruktur universal dalam memahami orang-orang dalam konteks mereka. Penelitian ini dilakukan dengan menggunakan indigenous psychology, yang menekankan studi tentang perilaku dan pikiran dalam konteks budaya (Kim \& Berry, 1993).

\section{Tempat Penelitian}

Penelitian ini penulis memfokuskan pada Tiga wilayah kecamatan, yaitu Kecamatan Tenggarong, Kecamatan Anggana dan Kecamatan Muara Muntai. Adapun alasan peneliti hanya mengambil Tiga kecamatan dikarenakan kecamatan yang terpilih penyebaran pupulasi masyarakat yang bersuku Kutai masih tergolong banyak dan kental suku kutainya.

\section{Unit Analisis}

Unit Analisis dalam penelitian menerangkan Subjective Well-Being PNS dan Non PNS yang Bersuku Kutai (studi Indigenous Psikology) dalam penelitian ini adalah: Persepsi PNS dan Non PNS Masyarakat suku Kutai terhadap pengalaman hidupnya yang terdiri dari evaluasi kognitif dan afeksi dan menjadikan kepuasan hidup menjadi faktor utama untuk mencapai kesejahteraan dan menekankan pada perilaku dan pikiran masyarakat dalam konteks budayanya.

Peneliti mengunakan teori Subjective Well-Being dari Diener (2000) sebagai perspektif teoritis. Dalam penelitian ini Subjective Well-Being didefinisikan sebagai persepsi seseorang terhadap pengalaman hidupnya dalam lingkup pekerjaan yang terdiri dari evaluasi kognitif dan afektif.

\section{Sampel Sumber Data}

Sumber data adalah segala sesuatu yang menjadi objek penelitian. Dalam hal ini sumber datanya adalah pegawai PNS dan Non PNS yang bersuku Kutai. Responden dalam penelitian ini berjumlah 200 Responden terdiri dari PNS dan Non PNS yang bersuku Kutai di tiga kecamatan yang ada di wilayah Kabupaten Kutai. Adapun kriteria responden penelitian ini adalah 1). PNS dan Non PNS dengan masa kerja minimal 2 tahun dengan alasan subyek sudah menguasai pekerjaan dan bisa menilai dan merasakan cocok atau tidak cocok pekerjaan tersebut 2). Usia $20-60$ tahun dengan alasan pada masa tersebut adalah masa usia produktif 3). Bersuku Kutai yang asli garis keturunan bersifat patrilineal, garis keturunannya ditarik dari pihak laki-laki. Model sampling dalam penelitian ini menggunakan teknik snow ball sampling.

\section{Teknik Pengumpulan Data}

Data Penelitian ini dikumpulkan melalui pertanyaan terbuka (open-ended questionnaire) yang dikembangkan berdasarkan Study Indigenous Psychology yang diperkenalkan oleh Kim \& Park (2006). Data penelitian ini juga ditunjang dengan data demografis responden, yang meliputi Jenis Kelamin, Usia, Lama Masa Kerja. Diener dan Oishi (2005,dalam Ningsih 2013) menyatakan bahwa sejauh mana faktor demografis tertentu dapat meningkatkan Subjective Well-Being tergantung dari nilai dan tujuan yang dimiliki seseorang, kepribadian dan kultur.

\section{Teknik Analisis Data}

Penelitian ini adalah Indigenous Psychology yang di desain oleh Kim\& Park (2006). Aitem yang digunakan berbentuk pertanyan terbuka menggunakan instrumen openended questionaire. Kim\& Park (2006) mendefinisikan indigenous psychology sebagai kajian ilmiah mengenai perilaku dan mental manusia yang bersifat pribumi, tidak dibawa dari daerah lain, dan didesain untuk masyarakatnya sendiri.

Analisis data dengan menggunakan pendekatan Indigenous Psychology. Dengan melakukan berberapa tahapan yaitu Preliminary coding, categorization, axial coding and cross-tabulations.

\section{Pengujian Keabsahan Data}


Penelitian ini dilakukan pada PNS dan Non PNS yang bersuku Kutai yang berada di berberapa wilayah di kabupaten Kutai Kartanegara.

Data yang berhasil dikumpulkan melalui open-ended questionnaire akan diproses (dilakukan koding dan kategorisasi) dengan jawaban responden yang dikumpulkan dinilai oleh tim penilai yaitu 3 orang rater, penentuan jumlah rater yang ada berdasarkan penelitian terdahulu dan berpengalaman dalam kategorisasi.

\section{HASIL DAN PEMBAHASAN}

Setting Penelitian ini adalah Wilayah Kabupaten Kutai Kartanegara. Kabupaten Kutai Kartanegara memiliki luas 27.263,10 $\mathrm{km}^{2}$ terletak antara $115^{0} 26^{\prime} 28^{\prime}$ ' BT$117^{0} 36^{\prime} 43^{\prime \prime}$ BT an $1^{0} 28^{\prime} 21$ LU-1 ${ }^{0} 08^{\prime} 06^{\prime \prime}$ LS. Kabupaten Kutai Kartanegara sendiri terbagi dalam 18 Wilayah kecamatan dan 238 desa/ kelurahan dengan pertumbuhan penduduk sebesar $3.92 \%$ per-tahun. Penduduk Kabupaten Kutai Kartanegara mencapai 870.306 (april2014) dengan kepadatan penduduk rata-rata $32 \mathrm{jiwa} / \mathrm{km}^{2}$.

Subjek dalam penelitian ini adalah PNS dan Non PNS yang bersuku Kutai, dengan jumlah subjek penelitiannya sebanyak 200 responden. Berikut disajikan data demografi subjek penelitian: Jenis Kelamin Responden diketahui bahwa sebanyak $55.5 \%$ yaitu berjenis kelamin lakilaki, dan $44.5 \%$ berjenis kelamin perempuan, Usia Responden diketahui bahwa sebanyak $48.0 \%$ yaitu berusia antara 31 sampai 40 tahun, Status Perkawinan Responden diketahui bahwa sebanyak $74.0 \%$ yaitu status perkawinannya yaitu sudah menikah, Pekerjaan Responden diketahui bahwa Pekerjaan PNS dan Non PNS adalah Sebanding, Masa Kerja Responden diketahui bahwa sebanyak $31.50 \%$ yaitu memiliki masa kerja antara 6 sampai 10 tahun.

Pengambilan data ini dilakukan dengan cara, memberikan questioner kepada responden secara langsung dan tahapan selanjutnya setelah pengumpulan data adalah proses tabulasi data. Peneliti menyalin satu demi satu jawaban responden sebanyak 200 orang, dari 5 soal pertanyaan yang tersedia. Jawaban-jawaban responden tersebut diberi kode urut untuk mempermudah peneliti saat mengecek jumlah responden yang ada dan masingmasing jawabannya

\section{Hasil Penelitian}

Temuan penelitian adalah hasil yang didapatkan dari sebuah penelitian yang telah dilakukan oleh seorang peneliti, baik dengan menggunakan metode observasi, wawancara (questioner) maupun dengan metode survey. Terdapat 5 pertanyaan yang harus di jawab oleh responden penelitian. Tahapan selanjutnya yaitu, tahap kategorisasi.

Pada tahap ini, peneliti mengelompokkan jawaban-jawaban responden sesuai dengan kategori yang telah dibuat oleh peneliti dan para reviewer. Para reviewer dalam penelitian ini berjumlah 3 orang. Adapun Fungsi para reviewer disini adalah untuk menghasilkan sebuah kesepakatan dalam menentukan suatu kategori, sehingga subjektivitas peneliti dapat terhindarkan. Pembentukkan kategori diambil dari kata kunci pertama jawaban responden, peneliti menganggap bahwa kata kunci pertama merupakan gambaran jawaban responden yang mewakili dari seluruh kalimat yang ada.

Setelah tahap kategorisasi selesai, peneliti kemudian melakukan proses koding tahap 1 dimana peneliti bersama para reviewer mendata kategori-kategori yang tersedia dari tiap pertanyaan, mulai dari jumlah kategori yang ada, sampai jumlah responden yang menjawab dalam setiap kategori. Kemudian koding tahap 2, disini peneliti dan para reviewer membentuk kategori yang lebih umum daripada koding sebelumnya yaitu pada koding tahap 1. Kategori umum ini didapatkan dari kategori-kategori yang maknanya hampir mendekati satu sama lain, sehingga kategori khusus yang saling berkesinambungan dapat dijadikan dalam satu kategori umum. Pada koding tahap 2 ini dijadikan dalam satu kategori yang sama.

Untuk mempermudah, berikut peneliti menjelaskan dan memberi gambaran dari 5 soal pertanyaan dari jawaban responden beserta hasil koding.

Soal no. 1 (Apakah Anda Puas dengan kehidupan Anda saat ini dan Bagaimana Anda menggambarkan Kepuasan Anda Tersebut ?) 
Tabel IV.7. Koding Tahap 1 soal no.1 (Kategorisasi Tingkat Kepuasan)

\begin{tabular}{|c|l|c|c|}
\hline No. & Kategori & Jumlah & \% \\
\hline 1 & Sangat Puas & 35 & 17.5 \\
\hline 2 & Puas & 119 & 59.5 \\
\hline 3 & Tidak Puas & 23 & 11.5 \\
\hline 4 & Lainya & 11 & 5.5 \\
\hline 5 & $\begin{array}{l}\text { Tidak Menjawab ( tidak } \\
\text { terkategorisasi) }\end{array}$ & 12 & 6.0 \\
\hline \multicolumn{2}{|l|}{ Jumlah Total } & 200 & 100 \\
\hline
\end{tabular}

Kelompok yang terkategori berada pada urutan nomor 1 sampai 4 , sedangkan kelompok yang tidak terkategori berada pada nomor 5 yang terdiri dari jawaban kosong dan jawaban yang tidak dapat dimasukkan dalam kategori manapun.

Tabel IV.9. Data Keseluruhan Kategori Umum Soal Nomor 1

\begin{tabular}{|c|l|c|c|}
\hline No. & Kategori Umum & Jumlah & \% \\
\hline 1 & Kepuasan Hidup & 68 & 34.0 \\
\hline 2 & Nilai Spritual & 67 & 33.5 \\
\hline 3 & Kebersamaan Keluarga & 25 & 12.5 \\
\hline 4 & Tercapainya tujuan hidup & 14 & 7.0 \\
\hline 5 & Kecukupan materi & 10 & 5.0 \\
\hline 6 & Pekerjaan & 4 & 2.0 \\
\hline 7 & Tidak Terkategorisasi & 12 & 6.0 \\
\hline \multicolumn{2}{|l|}{ Jumlah Total } & 200 & 100 \\
\hline
\end{tabular}

Berdasarkan tabel di atas, diketahui bahwa kategori Kepuasan Hidup saat ini memiliki skor tertinggi yaitu sebesar $34.0 \%$ dengan responden sebanyak 68 orang.

Soal no. 2 (Apa yang membuat Anda puas dengan pekerjaan Anda dan Pencapaian apa yang Anda inginkan?)

Tabel IV.10. Koding Tahap 1 soal no.2 (Kategorisasi Tingkat Kepuasan)

\begin{tabular}{|c|l|c|c|}
\hline No. & Kategori & Jumlah & \% \\
\hline 1 & Sangat Puas & 17 & 8.50 \\
\hline 2 & Puas & 140 & 70.0 \\
\hline 3 & Tidak Puas & 36 & 18.0 \\
\hline 4 & Lainya & 7 & 3.50 \\
\hline 5 & $\begin{array}{l}\text { Tidak Menjawab ( tidak } \\
\text { terkategorisasi) }\end{array}$ & 0 & 0 \\
\hline \multicolumn{2}{|l|}{ Jumlah Total } & 200 & 100 \\
\hline
\end{tabular}

Kelompok yang terkategori berada pada urutan nomor 1 sampai 4, sedangkan kelompok yang tidak terkategori berada pada nomor 5 yang terdiri dari jawaban kosong dan jawaban yang tidak dapat dimasukkan dalam kategori manapun.

Tabel IV.12. Data Keseluruhan Kategori Soal Nomor 2

\begin{tabular}{|c|l|c|c|}
\hline No. & Kategori & Jumlah & \% \\
\hline 1 & Terlaksananya Pekerjaan & 76 & 38.00 \\
\hline 2 & Pencapaian / keinginan & 59 & 29.50 \\
\hline 3 & Materi & 22 & 11.00 \\
\hline 4 & Hubungan Sosial & 20 & 10.0 \\
\hline 5 & Penghargaan Pribadi & 13 & 6.50 \\
\hline 6 & Tidak Terkategorisasi & 10 & 5.00 \\
\hline \multicolumn{2}{|l|}{ Jumlah Total } & 200 & 100 \\
\hline
\end{tabular}

Berdasarkan tabel di atas, diketahui bahwa kategori terlaksananya pekerjaan saat ini memiliki skor tertinggi yaitu sebesar $38.00 \%$ dengan responden sebanyak 76 orang. Dari hasil kategori pertanyaan soal nomor 1 dan nomor 2 disatukan menjadi satu kelompok sehingga mendapatkan kesimpulan dari data kategori soal nomor 1 dan nomor 2 yaitu sebagai berikut :

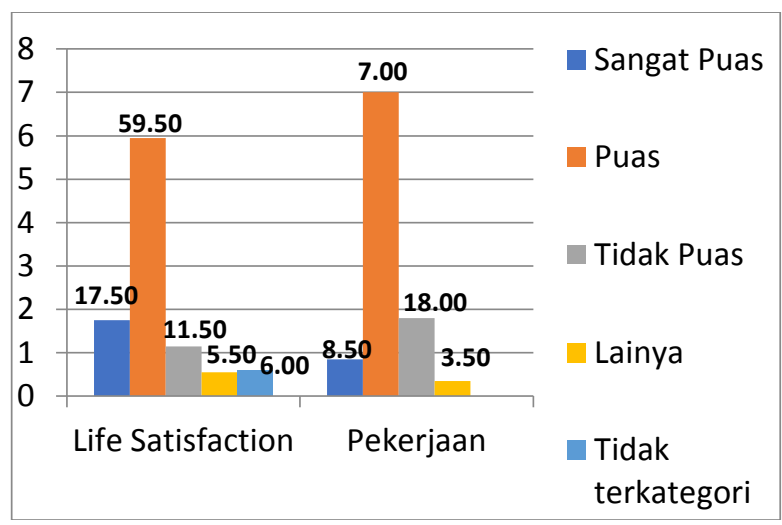

Berdasarkan grafik tingkat kepuasan di atas, diketahui bahwa skor tertinggi di duduki oleh kategori Puas berdasarkan dari dua 
pertanyaan Komponen kognitif SWB yaitu kepuasan hidup secara global dengan nilai $59.50 \%$ sebanyak 119 orang dan kepuasan pada domain tertentu (pekerjaan) dengan nilai $70.00 \%$ sebanyak 140 orang.

Tabel IV.15. Data Keseluruhan Kategori Soal Nomor 1 dan Nomor 2, Kategori sepesifik ke kategori Umum

\begin{tabular}{|c|c|c|c|}
\hline No. & $\begin{array}{l}\text { Komponen } \\
\text { Kognitif }\end{array}$ & Kategori Umum & $\begin{array}{c}\text { Juml } \\
\text { ah }\end{array}$ \\
\hline \multirow{7}{*}{1} & \multirow{7}{*}{$\begin{array}{l}\text { Kepuasan Hidup } \\
\text { Life Satisfaction) }\end{array}$} & Kepuasan Hidup & 68 \\
\hline & & Nilai Spritual & 67 \\
\hline & & $\begin{array}{l}\text { Kebersamaan } \\
\text { Keluarga }\end{array}$ & 25 \\
\hline & & $\begin{array}{l}\text { Tercapainya tujuan } \\
\text { hidup }\end{array}$ & 14 \\
\hline & & Kecukupan materi & 10 \\
\hline & & Pekerjaan & 4 \\
\hline & & Tidak Terkategorisasi & 12 \\
\hline \multicolumn{3}{|c|}{ Jumlah Total } & 200 \\
\hline \multirow{6}{*}{2} & \multirow{6}{*}{$\begin{array}{l}\text { Kepuasan Hidup } \\
\text { Pada Domain } \\
\text { tertentu } \\
\text { (Pekerjaan) }\end{array}$} & $\begin{array}{l}\text { Terlaksananya } \\
\text { Pekerjaan }\end{array}$ & 76 \\
\hline & & $\begin{array}{l}\text { Pencapaian } \\
\text { keinginan }\end{array}$ & 59 \\
\hline & & Materi & 22 \\
\hline & & Hubungan Sosial & 20 \\
\hline & & Penghargaan Pribadi & 13 \\
\hline & & Tidak Terkategorisasi & 10 \\
\hline \multicolumn{3}{|c|}{ Jumlah Total } & 200 \\
\hline
\end{tabular}

Berdasarkan tabel di atas, diketahui bahwa kategori kepuasan hidup ( Life Satisfaction) mempunyai sekor tertinggi $34.00 \%$ pada kategori kepuasan hidup dengan jumlah 68 responden sedangkan pada kategori kepuasan pada pekerjaan mempunyai tingkat sekor tertinggi $38.00 \%$ pada pelaksaan pekerjaan dengan jumlah 76 responden.

Soal no. 3 (Apakah Sistem kekeluargaan khas kutai yang disebut "bubuhan" berperan penting dan membantu Anda dalam pencapaian pekerjaan tersebut?)

Tabel IV.15. Koding soal Nomor 3 ( Ciri Khas "Kutai”)

\begin{tabular}{|l|l|l|l|}
\hline No. & Kategori & Jumlah & $\%$ \\
\hline
\end{tabular}

\begin{tabular}{|c|l|c|c|}
\hline 1 & Sangat Membantu & 54 & 27.00 \\
\hline 2 & Membantu & 57 & 28.50 \\
\hline 3 & Tidak Membantu & 47 & 23.50 \\
\hline 4 & Lainya & 27 & 13.50 \\
\hline 5 & $\begin{array}{l}\text { Tidak Menjawab (tidak } \\
\text { terkategorisasi) }\end{array}$ & 15 & 7.50 \\
\hline \multicolumn{2}{|l|}{ Jumlah Total } & 200 & 100 \\
\hline
\end{tabular}

Berdasarkan tabel diatas diketahui Nilai responden yang menjawab dari Kategori 1 yaitu Sangat Membantu sebanyak 27.00\%, kategori 2 yaitu Membantu sebanyak $28.50 \%$,. Kategori 3 yaitu tidak membantu sebanyak $23.50 \%$. kategori empat yaitu lainnya sebanyak $13.50 \%$. dan kategori lima tidak terkategorisasi sebanyak $7.50 \%$ dari total responden sebanyak 200 responden.

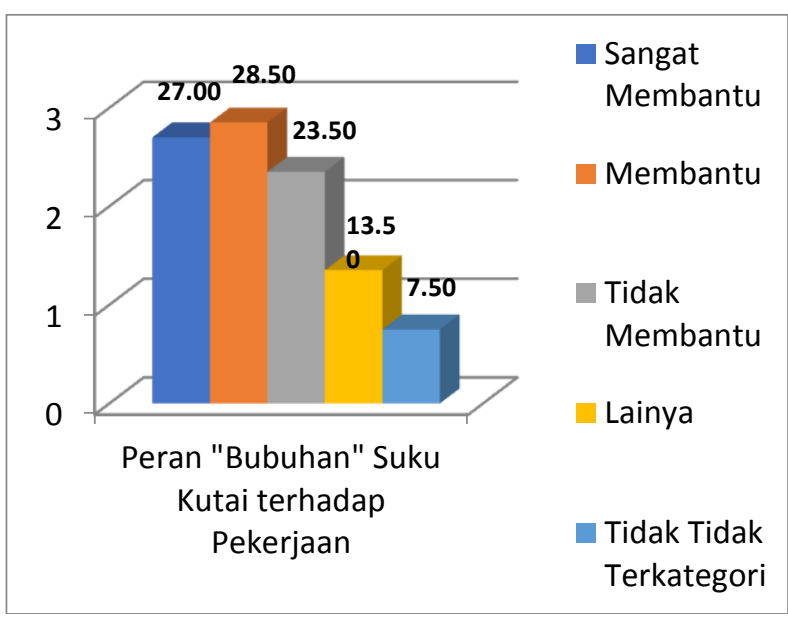

Pada grafik diatas menjelaskan bahwa pertanyaan yang merujuk pada peran penting "bubuhan" suku kutai pada pencapaian pekerjaan dengan nilai tertinggi $28.50 \%$ adalah Kategori Membantu dengan jumlah 57 responden. Dengan demikian dapat disimpulkan Sistem kekeluargaan khas kutai yang disebut "bubuhan" dari hasil jawaban responded kelompok tersebut berperan penting dan membantu dalam pencapaian pekerjaan.

Soal no. 4 (Berikan gambaran, pristiwaperistiwa apa yang menyenangkan dalam pekerjaan Anda?) 


\begin{tabular}{|c|l|c|c|}
\hline No & \multicolumn{1}{|c|}{ Kategori } & Jumlah & $\%$ \\
\hline 1 & $\begin{array}{l}\text { Aktif (Hubungan } \\
\text { Sosial) }\end{array}$ & 64 & 32.00 \\
\hline 2 & Antusias & 52 & 26.00 \\
\hline 3 & $\begin{array}{l}\text { Berminat Akan } \\
\text { sesuatu }\end{array}$ & 34 & 17.00 \\
\hline 4 & Bangga & 29 & 14.50 \\
\hline 5 & Gembira & 16 & 8.00 \\
\hline 6 & Lainya & 5 & 2.50 \\
\hline 7 & $\begin{array}{l}\text { Tidak } \\
\text { Terkategorisasi }\end{array}$ & 0 & 0 \\
\hline \multicolumn{2}{|l|}{ Jumlah Total } & 200 & 100 \\
\hline
\end{tabular}

Tabel IV.16. Koding soal Nomor 4 ( Komponen Afektif Positif )

Berdasarkan Tabel diatas, kelompok yang terkategori berada pada urutan nomor 1 sampai 6, sedangkan kelompok yang tidak terkategori berada pada nomor 7 yang terdiri dari jawaban kosong dan jawaban yang tidak dapat dimasukkan dalam kategori manapun. Selanjutnya koding tahap 2 dilakukan untuk mengelompokkan kategorikategori yang spesifik ke dalam satu kategori umum, untuk lebih mudah dipahami.

Tabel IV.18. Data Keseluruhan Kategori Soal Nomor 4

\begin{tabular}{|c|c|c|c|}
\hline No & Kategori & Jumlah & $\%$ \\
\hline 1 & Tugas / Pekerjaan & 46 & 23.00 \\
\hline 2 & Pertemanan & 45 & 22.50 \\
\hline 3 & Melayani & 39 & 19.50 \\
\hline 4 & Materi & 32 & 16.00 \\
\hline 5 & Tanggung Jawab & 10 & 5.00 \\
\hline 6 & Di puji / diapresiasi & 8 & 4.00 \\
\hline 7 & Tidak Terkategorisasi & 20 & 10.00 \\
\hline \multicolumn{2}{|c|}{ Jumlah Total } & 200 & 100 \\
\hline
\end{tabular}

Berdasarkan tabel di atas, diketahui bahwa kategori tugas / pekerjaan saat ini memiliki skor tertinggi yaitu sebesar $23.00 \%$ dengan responden sebanyak 46 orang. Dengan demikian dapat disimpulkan bahwa gambaran, pristiwa menyenangkan menurut suku kutai yang bekerja sebagai PNS dan Non PNS adalah tugas/pekerjaan antara lain Menyelesaikan pekerjaan tepat waktu, Dinas

\begin{tabular}{|c|l|c|c|}
\hline No & \multicolumn{1}{|c|}{ Kategori } & Jumlah & $\%$ \\
\hline 1 & Kecewa & 94 & 47.00 \\
\hline 2 & Khawatir & 47 & 23.50 \\
\hline 3 & Takut & 17 & 8.50 \\
\hline 4 & Bermusuhan & 13 & 6.50 \\
\hline 5 & Lekas Marah & 5 & 2.50 \\
\hline 6 & Lainya & 24 & 12.00 \\
\hline 7 & Tidak Terkategorisasi & 0 & 0 \\
\hline \multicolumn{2}{|c|}{ Jumlah Total } & 200 & 100 \\
\hline
\end{tabular}

luar dan dalam kota serta Liburan.

Soal no. 5 (Berikan gambaran, pristiwaperistiwa yang tidak menyenangkan dalam pekerjaan Anda?)

Tabel IV.19. Koding soal Nomor 5 ( Komponen Afektif negatif )

Berdasarkan Tabel diatas, kelompok yang terkategorisasikan berada pada urutan nomor 1 sampai 6, sedangkan kelompok yang tidak terkategorisasikan berada pada nomor 7 yang terdiri dari jawaban kosong dan jawaban yang tidak dapat dimasukkan dalam kategori manapun.

Tabel IV.21. Koding soal Nomor 5 ( Komponen Afektif negatif )

\begin{tabular}{|c|l|c|c|}
\hline No & \multicolumn{1}{|c|}{ Kategori Umum } & Jumlah & $\%$ \\
\hline 1 & $\begin{array}{l}\text { Konflik dengan Rekan } \\
\text { Kerja }\end{array}$ & 42 & 21.00 \\
\hline 2 & $\begin{array}{l}\text { Bekerja Tidak Sesuai } \\
\text { tupoksi }\end{array}$ & 28 & 14.00 \\
\hline 3 & Masalah Pribadi & 28 & 14.00 \\
\hline 4 & Masalah teknis & 25 & 12.50 \\
\hline 5 & Masalah Keuangan & 21 & 1.050 \\
\hline 6 & $\begin{array}{l}\text { Hubungan dengan } \\
\text { masyarakat / klien }\end{array}$ & 14 & 7.00 \\
\hline
\end{tabular}




\begin{tabular}{|c|l|c|r|}
\hline 7 & $\begin{array}{l}\text { Tidak ada } \\
\text { apresiasi/pujian }\end{array}$ & 12 & 6.00 \\
\hline 8 & $\begin{array}{l}\text { Tidak diberi } \\
\text { kepercayaan/tanggung }\end{array}$ & 6 & 3.00 \\
\hline 9 & Lainya & 24 & 12.00 \\
\hline 10 & Tidak Terkategorisasi & 0 & 0 \\
\hline \multicolumn{2}{|c|}{ Jumlah Total } & 200 & 100 \\
\hline
\end{tabular}

\section{Nilai Spiritual}

Nilai spiritual mengacu pada peroses memenuhi atau telah terpenuhinya target individu dalam hal spiritual. Target spiritual mencakup aktivitas-aktivitas yang mencerminkan keyakinan terhadap agama. Pendapat Diener (2009) menyatakan bahwa secara umum orang yang religius cenderung untuk memiliki tingkat well being yang lebih tinggi, dan lebihn spesifik. Diener (2009) juga mengungkapkan bahwa hubungan positif antara spiritualitas dan keagamaan dengan subjective well-being berasal dari makna dan tujuan jejaring sosial dan sistem dukungan yang diberikan oleh organisasi keagamaan.

3. Kebersamman Keluarga Ikatan atau kebersamaan keluarga tercermin dari adanya dukungan materi dan non materi dari keluarga kertika menjalankan aktivitas. Pendapat dari Oetami dan Yuniarti (2011: 109) yang diketahui bahwa peristiwa yang membuat seseorang paling bahagia adalah peristiwa yang berhubungan dengan keluarga.

Non PNS,dan Faktor-faktor apa saja yang mempengaruhi Subjective Well-Being masyarakat Kutai yang bekerja sebagai PNS dan Non PNS.

Gambaran Bagaimana Subjective WellBeing masyarakat Kutai yang bekerja sebagai PNS dan Non PNS adalah sebagai berikut:

\section{Kepuasan hidup saat ini (rasa puas, bahagia dan temtram/damai)}

Kategori kepuasan hidup (Life Satisfaction) adalah penilaian kognitif seseorang terhadap kehidupannya seperti perasaan aman, nyaman, dan bahagia pada kehidupan yang dijalaninya. Menurut masyarakat suku Kutai ketika mereka memiliki rasa bahagia, tanpa beban pikiran, rasa nyaman, rasa tentram/damai, rasa aman, rasa puas,dan hidup tanpa ada masalah sudah menjadi suatu kepuasan hidupnya dan memperoleh kesejahteraan hidupnya. Life satisfaction (Diener, 1994) merupakan penilaian kognitif seseorang mengenai kehidupannya, apakah kehidupan yang dijalaninya berjalan dengan baik.

4. Kesuksesan Pekerjaan Kesuksesan pekerjaan menurut masyarakat suku Kutai dapat tercapainya kesejahteraan hidup jika memiliki pekerjaan, kesuksesan dapat diraih, dan memiliki keberuntungan. Hasil penelitian Asri Mutiara Putri (2009) yang menunjukkan bahwa individu yang bekerja lebih bahagia dibandingkan dengan individu yang tidak bekerja.

5. Kecukupan Materi Kategori kecukupan materi menurut masyarakat Suku Kutai adalah pada saat kebutuhan hidup mereka tercukupi (sandang, pangan, papan), mapan dalam segala hal, memiliki penghasilan, materi/uang juga tercukupi dan tidak punya hutang kepada orang lain. Penelitian di Barat, diketahui bahwa hasil studi kasus yang diteliti oleh Fafchamps dan Kebede (2008) terdapat hubungan positif antara subjective well-being dan kekayaan seseorang di suatu kota. Artinya bahwa semakin seseorang memiliki kekayaan yang banyak maka subjective well-being akan mudah dicapai. 


\section{Pencapaian/Keinginan}

Kategori

Pencapaian Keinginan meliputi tercapainya keinginan/harapan, sudah memiliki pekerjaan, dan sudah dapat memuaskan diri sendiri. Menurut Engler (dalam Jarvis, 2009: 98) pandangan Maslow mengenai upaya keras manusia demi pencapaian prestasi/tujuan hidup personal terlalu terikat pada budaya dengan terpaku pada budaya individualistik di Amerika Serikat

7. Hubungan Sosial Hubungan yang positif dengan orang lain berkaitan dengan subjective well-being, karena dengan adanya hubungan yang positif tersebut akan mendapat dukungan sosial dan kedekatan emosional. Penelitian yang dilakukan oleh Seligman (dalam Diener \& Scollon,2003) menunjukan bahwa semua orang yang paling bahagia memiliki kualitas hubungan sosial yang dinilai baik. Diener dan Scollon (2003) menyatakan bahwa hubungan yang dinilai baik tersebut harus mencakup dua dari tiga hubungan sosial berikut ini, yaitu keluarga, teman, dan hubungan romantis.

Berdasarkan hasil jawaban secara keseluruhan, dapat disimpulkan bahwa kesejahteraan hidup Suku Kutai ialah apabila seseorang memiliki Rasa puas akan kehidupan saat ini, selalu bersyukur, kebersamaan dalam keluarga, terlaksananya pekerjaan, kecukupan materi, tercapainya / keinginan dan terjalin hubungan sosial yang baik.

\section{Faktor-faktor yang mempengaruhi Subjective well-being masyarakat Kutai yang bekerja sebagai PNS dan Non PNS}

1. Faktor Hubungan Sosial Hubungan yang positif dengan orang lain berkaitan dengan subjective wellbeing, karena dengan adanya hubungan yang positif tersebut akan mendapat dukungan sosial dan kedekatan emosional. Pada dasarnya kebutuhan untuk berinteraksi dengan orang lain merupakan suatu kebutuhan bawaan.

\section{Faktor Kecukupan Materi /} Permasalahan Keuangan Faktor kecukupan materi menurut karyawan bersuku Jawa adalah apabila kebutuhan hidup tercukupi, penghasilan cukup, ekonomi/uang cukup, memiliki tempat tinggal, memiliki tabungan/investasi, dapat hidup berhemat, memiliki fasilitas, dapat mengontrol pengeluaran, dapat memanajemen pendapatan, dapat hidup secara mapan, dan tidak punya hutang.

3. Faktor Kesuksesan pekerjaan Faktor kesuksesan pekerjaan menurut masyarakat Kutai juga dapat mempengaruhi tercapainya kesejahteraan hidup jika memiliki pekerjaan, kesuksesan dapat diraih, dan memiliki keberuntungan.

4. Karakter pribadi Suku Kutai Karakter pribadi orang kutai optimisme dan percaya diri. Suku Kutai lebih optimis tentang masa depannya mereka merasa lebih bahagia dan puas atas hidupnya dibandingkan dengan orang pesimis yang mudah menyerah dan putus asa jika suatu hal terjadi tidak sesuai dengan keinginannya.

Secara keseluruhan, diketahui bahwa masyarakat suku kutai yang bekerja sebagai PNS dan Non PNS sebagian besar menganggap faktor-faktor yang mempengaruhi subjective well-being dalam hidupnya adalah faktor hubungan sosial ,faktor kecukupan materi / permasalahan Keuangan, dan Faktor kesuksesan pekerjaan

Berdasarkan keterangan di atas, diketahui bahwa sebagian besar orang Kutai selalu bersyukur dengan kehidupan yang di hadapi sekarang dan selalu menjalin hubungan baik pada orang lain, sehingga mereka merasa sudah mencapai kesejahteraan hidup. Adapun hasil temuan peneliti yang bersumber dari pertanyaan seberapa penting peran kekeluargan "Bubuhan" di lingkungan mereka saat ini terjawab dengan hasil Berperan / membantu pada tercapainya pekerjaan. Dan menurut dari hasil data demografis terkait dengan nilai kepuasan hidup pada masyarakat Kutai sangat sesuai yaitu dimana hasil kategori yang diperoleh memperlihatkan bahawa 
tingkat kepuasan didukung oleh masyarakat yang berusia diatas 30 tahun, dan memiliki setatus perkawinan sudah menikah serta mempunyai pekerjaan yang baik dan masa kerja diatas 6-10 tahun dan ini didominasi oleh wanita pekerja.

\section{KESIMPULAN}

Berdasarkan hasil penelitian di lapangan yang dilakukan pada masyrakat Suku Kutai yang bekerja sebagai PNS dan Non PNS dapat disimpulkan bahwa:

(1) Subjective Well-Being masyarakat Suku Kutai adalah kondisi dimana seseorang memiliki Rasa puas akan kehidupan saat ini, selalu bersyukur dengan terpenuhinya kebutuhan hidup dan kebersamaan keluarga yang harmonis serta terjalinya hubungan sosial dan terlaksananya pekerjaan dengan baik untuk memperoleh pencapaian/keinginan. Dan tidak ada perbedaan pengertian SWB menurut masyarakat Suku Kutai yang bekerja sebagai PNS dan Non PNS

(2) Faktor-faktor yang mempengaruhi SWB masyarakat Suku Kutai, Diketahui bahwa faktor-faktor yang mempengaruhi kesejahteraan ialah faktor hubungan sosial, faktor kecukupan materi dan faktor kesuksesan

\section{DAFTAR PUSTAKA}

Anggoro, W.J., \& Widiarso, W., (2010). Konstruksi dan Identifikasi Properti Psikometris Instrumen Pengukuran Kebahagiaan Berbasis Pendekatan Indigenous Psychology: Studi Multitrait- Multimethod. Jurnal Psikologi UGM, Vol 37, 176-188

Anisa \& Zulkarnain (2013). Komitment Terhadap Organisasi Ditinjau dari
Kesejahteraan Psikologis Pekerja. INSAN Vol. 15 No.1 54-62

Ariati, J. (2010). Subjective well-being (Kesejahteraan Subjektif) dan Kepuasan Kerja pada Staf Pengajar (Dosen) di Lingkungan Fakultas Psikologi Universitas Diponegoro. Jurnal Psikologi Undip, 8(2), 117-123.

Apriyanto, D., \& Harini, R. (2013). Dampak Kegiatan Pertambangan Batubara Terhadap Kondisi Sosialekonomi Masyarakat Di Kelurahan Loa Ipuh Darat, Tenggarong, Kutai Kartanegara. Jurnal Bumi Indonesia, 1(3).

Berita Resmi Statistik, BPS Propinsi Kalimantan Timur. (2015). Indeks Kebahagiaan Kalimantan Timur (termasuk Kalimantan Utara) tahun 2014, (No. 12/02/64/XVIII/Th/5-22015).

BPS Propinsi Kalimantan Timur. (2015). Jumlah dan Persentase Penduduk Miskin Serta Garis Kemiskinan Menurut Kabupaten/Kota, 2014

BPS Propinsi Kalimantan Timur. (2015). Penduduk Menurut Kabupaten/Kota tahun 2012-2014 Hasil Proyeksi

BPS Propinsi Kalimantan Timur. (2015). Tingkat Pengangguran Terbuka Menurut Kabupaten/Kota, 2012 2014

BPS. (2011). Kondisi Sosial Ekonomi dan Indikator Penting Kalimantan Timur Edisi Januari 2011. Badan Pusat Statistik Provinsi Kalimantan Timur.

Carr, A., (2004) Positive psychology: The science of happiness and human strengths. New York : BrunnerRoutledge

Center For Indigenous \& Cultural Psychology. Fakultas Psikologi Universitas Gadjah Mada. 2015 
Diener, E. (2009). Subjective well-being. In The science of well-being (pp. 1158). Springer Netherlands.

Diener, E., Lucas, R. E., \& Oishi, S. (2009)

Subjective Well-Being.

Diener, E. (2000). Subjective well-being: The science of happiness and a prc 197 for a national index. Ame psychologist, 55(1), 34.

Diener, E., Suh, E. M., Lucas, R. E., \& Smith, H. L. (1999). Subjective Weil-Being: Three Decades of Progress. Psychological Bulletin, 125(2), 276-302.

E-Book. W. Paul Vogt,Elaine R. Vogt, Dianne C.Gardner,Lynne M. Haeffele. Selecting the Right Analyses for your Data. Quantitative, Qualitative, and Mixed Methods. The Guilford Press. New York. London. 2014

E-Book. Uichol Kim, Kuo-Shu Yang, KwangKuo Hwang. Indigenous and Cultural Psychology. 2006 Springer. United States of America

Gambaran Umum Kabupaten Kutai Kartanegara. Diakses tgl 03 Mei 2015. http://kabupaten.kutaikartanegara.co $\underline{\mathrm{m}}$

Jumlah PNS Kukar terbanyak di Indonesia. Diakses tgl 03 Mei 2015. http://kaltim.tribunnews.com/2012/02 121

Kim, U., \& Berry, J.W. (1993). Indigenous Psychology: Research and Experience in Cultural Contex. Volume 17, Cross Cultural Research and Methodology Series.

Kim, U., Park, Y. S., \& Park, D. (2000). The Challenge of Cross-Cultural Psychology The Role of the Indigenous Psychologies. Journal of Cross-Cultural Psychology, 31(1), 63-75.

Kim, U., \& Park, Y. S. (2006). The scientific foundation of indigenous and cultural psychology. In Indigenous and Cultural Psychology (pp. 27-48). Springer US.

Keuangan, B. P. (2013). Laporan Keuangan Pemerintah Pusat.".

Kompas.com/read/2015/10/01/13433661/Tam bang.Batubara.Sumbang.Angka.PHK .Terbesar.di.Kaltim. di akses pada tanggal 26/5/2016

Kaltim.prokal.co/.../241383-badai-phkmenyapu-kaltim. Diakses tgl. $26 / 5 / 2016$

Mangan Ora Mangan Ngumpul Sebuah Falsafah Hidup Orang Jawa. Diakses tanggal 25 Februari 2015 dari http://vii2u.blogspot.com/2013/05/ma ngan-ora-mangan-kumpulsebuah.html

Murti Mujamiasih, Rahmawati Prihastuti \& Sugeng Hariyadi. ( 2013 ). Subjective Well-Being (SWB): Studi Indigenous Karyawan Bersuku Jawa. JSIP (2). ISNN 2252-6838

Moleong, Lexy J. 2007. Metodologi Penelitian Kualitatif Edisi Revisi. Bandung: PT REMAJA ROSDAKARYA

Morissan, M.A. 2012. Metode Penelitian Survei. Jakarta: Kencana

Ningsih, D. A. (2013). Subjective Well Being Ditinjau dari Faktor Demografi (Status Pernikahan, Jenis Kelamin, Pendapatan). Jurnal Online Psikologi, 1(2).

Prof. Dr. H. Noeng Muhadjir. Psikologi Positif. Permodelan The High Talenter For The Normal People. 2013

Pedoman Penulisan Skripsi. Fakultas Psikologi Universitas 17 Agustus 1945 Samarinda. April 2014

Primasari, A., \& Yuniarti, K. W. (2012). What make teenagers happy? An exploratory study using indigenous psychology approach. International 
Journal of Research Studies in Psychology, 1(2)

Rice, T.W., \& Steele, B.J.,(2004).Subjective well-being and culture across time and space.Journal of Cross-Cultural Psychology.Vol.35, 633-647

Rusbiantoro, (2011). Pengunaan Kata Sapaan Dalam Bahasa Melayu Kutai. Thesis. Pasca Sarjana Universitas Diponegoro Semarang

Sejarah Kesultanan Kutai Kartanegara. Diakses tgl 03 Mei 2015. http://kesultanan.kutaikartanegara.co $\underline{\mathrm{m}}$

Sejarah-suku-kutai-di-kalimantan-timur.html, Dia akses tgl 23 Mei 2016

Seligman, M. E. P.,(2005). Authentic Happiness. (diterjemahkan oleh: Eva Yulia Nukman). Bandung: Mizan Media Utama

Sepuluh Serikat Pekerja Melapor Ke Disnaker (2015, Februari). Bontangpost (Online) diakses tanggal 1 Maret 2015

darihttp://www.bontangpost.co.id/20

15/02/10-serikat-pekerja-melapor-

ke.html

Suku Jawa. Diakses tanggal 3 Maret 2015 dari http://id.wikipedia.org/wiki/Suku Ja wa

Suku Kutai. Diakses tanggal 3 Maret 2015 dari http://id.wikipedia.org/wiki/Suku_Ku $\underline{\text { tai }}$

Tsegay, S. M., \& Ashraf, M. A. (2015). The influence of senior secondary school teachers on students' achievement in Gao-Kao. International Journal of Research Studies in Education, 4(4).

Utami, M. S. (2009). Keterlibatan dalam kegiatan dan kesejahteraan subjektif mahasiswa. Jurnal Psikologi, 36(2), 144-163.
Wilayah Kesultanan Kutai kartanegara. Diakses tgl 03 Mei 2015. http://kesultanan.kutaikartanegara.co $\underline{\mathrm{m}}$

Wilayah kabupaten Kutai kartanegara. Diakses tgl $03 \quad$ Mei 2015. http://kabupaten.kutaikartanegara.co $\underline{\mathrm{m}}$

Wijayanti, H., \& Nurwianti, F., (2010). Kekuatan Karakter dan Kebahagian pada Suku Minang.Jurnal Psikologi, Vol. 3, No 2, 114-122

Wahyu Jati Anggoro \& Wahyu Widhiarso ( 2010 ). Konstruksi dan Indentifikasi Properti Psikometris Instrumen Pengukuran Kebahagiaan Berbasis Pendekatan Indigenous Psychologis : Studi Multritrait- Multimethod. Jurnal Psikologi. Vol.37.No.2. 176-188

Wiratama Eki. (2014). Kesultanan Kutai Kartanegara: Perkembangan Islam Di Indonesia. Fakultas Ilmu Pengetahuan Budaya. Universitas Indonesia. Depok 